\title{
Research to improve enterprise financial report limitations
}

\author{
Fengnan Zhang \\ North China Electric Power University, China \\ 827073077@qq.com
}

Keywords: the current financial report, the defect, Improvement measures.

\begin{abstract}
In contemporary China, the network era changed the whole social and economic structure of production, to break the traditional enterprise management model and accounting model. Exceptionally rapid development of information technology, especially triggered a wave of global information network technology has had a great impact on traditional social every corner of the network, digital, intelligent has become the main theme of our era. In the existing financial reporting system can meet the requirement of the current economic development, cannot satisfy the user to the risk information and uncertain information disclosure requirements. Therefore, should be in line with the full disclosure, the principle of real-time report, the foresight to predict, to improve the financial report. The specific idea is: social responsibility report, forecast financial report, comprehensive income report and division. Finally, this article also puts forward the new ideas of financial reporting system, which is the innovation of this article.
\end{abstract}

\section{Background and significance}

Accounting is recognized as international "the language of business", is the important medium of communication of the domestic market and international market. After entering the WTO and the globalization trend of the now, the international common language, accounting internationalization has caused extensive concern of the people from all walks of life. Accounting history tells us that the change of social economic environment leads to the change of the accounting information user demand, and the change of the requirements of the accounting information can promote the development of financial accounting. The existing financial reporting system main body for a long period of time satisfying the requirements of social enterprise real fair disclosure of accounting information needs. In the existing financial reporting system including financial statements (balance sheet, income statement, the cash flow statement and the related schedule, statement of changes in owners' equity), four reports, notes, financial fact sheet. Therefore, the current financial reporting system already can not adapt to the knowledge economy era of enterprise information disclosure requirements, how to improve the existing financial reporting has become a top priority.

\section{The limitations of enterprise financial reporting system}

The present financial report there is a lot of problems, such as it is difficult to get report user information of the actual demand, the risk information disclosure enough, and so on. Demand for is probably the most difficult in the development, the key and the most error-prone and most in need of communication activities. Access to tend to have the wrong understanding of demand: the user know what demand, we have to do is talk with them from their requirements, just ask the target characteristics of the user's system, what to do, what kind of system appropriate to business needs, but the demand is not so simple, actually the communication path was full of thorns.

Users and developers often unconsciously has the idea of a "us and them", produce a kind of antagonistic, put each other in opposite, each side to define your own "boundary", just want to their own interests while ignoring each other's ideas. They communicate by documents, records and dialogue, rather than as a cooperation to identify and determine the requirements to complete the task as a whole. Practice proved that this method is not correct, will not bring some benefits to both sides, 
good communication and relationship with no led to misunderstanding and ignore the important information.

Financial report mainly provide historical information to reflect the enterprise future operating results and financial condition. Therefore, the current financial report generally lack of forward-looking information and predictive information, and a lot of information to the user need is career prospects. Although historical information to a certain extent, can predict the future, but must not be equated to represent the future.

\section{3. enterprise financial report improvement measures}

\subsection{Improve the reporting system.}

The current financial report is based on continuous operation and accounting assumptions phases, according to the year, month to prepare. This report in the economic life under the condition of relatively stable, is useful for decision makers, which they can accurately predict the next year and even financial situation for years to come. But in the product life cycle shorten, the enterprise business activities uncertainties enhance economic environment, accounting information decision usefulness period greatly shortened. For real-time reporting system, different countries have different rules, requirements and contents of the disclosure is not the same. Our country enterprise in practice can be achieved by other financial reports or disclosed in a separate social responsibility report form. Value-added table is one of the more perfect social responsibility report way in the world, our country should promptly value-added table establishment method, correlation criterion, value-added table will be built into the financial reporting system in our country as soon as possible.

\subsection{The scientific management system.}

In the 21st century, our country will be on the road of socialism with Chinese characteristics to realize the great rejuvenation of the Chinese nation. In order to accomplish this goal, China must deal with a series of challenges: (1) advancing the modernization construction, the complete reunification of the motherland, safeguard world peace and promote common development of the three major historical tasks; (2) in 2020 to achieve the comprehensive construction affluent society's goal; (3) improve the national competitiveness, and to participate in the global competition.

\subsection{Everything from global thinking more.}

May see from the FASB accounting elements definition, the current financial report mode of financial report or financial statements is basically a historical summary of accounting data records. Although the proposed accounting goal is to "decision usefulness" point of view, but this is not the case, and it also deviating and accrual accounting confirmation request. So, we should from the more basic, a higher level of accounting theory, accounting basic assumption, accounting goal and accounting object, standing on the height of the global unity of coordination processing. In fact, attaches great importance to the history of economic activity and ignore now future economic activity, in particular, to a great extent, is due to only learn the value of accounting object is simple or past values of sport, and dismissed as an accounting object values of sport can cover the past, present and future three points.

\section{Development trends and prospects of the enterprise's financial report}

The development of the enterprise financial environment changes made to demand changes in the existing financial report calls for more and more high, although these voices are mostly from accounting academia, but there are also many from users of accounting information. Improve financial reports suggest that opinions vary, unable to agree.

Future financial report on pricing mode to multiple valuation model, from historical cost to fair value measurement, consider the factor of inflation at the same time; In the scope of disclosure of information will have a large extend, will reflect the information of non-monetary, a lot like on enterprise human resources assets, intangible assets, digital information, financial derivatives, etc. This financial report mode by increasing the overall earnings report, can let the statement users get 
more clearly information on all of a firm's financial performance, better meet the information users of enterprise financial information especially reflect the requirements of the future cash flow forecast information.

Also due to the rapid development of information technology, EDI, GPS, GIS, Bar code and RF of a large number of applications, such as the cost of the development of reverse logistics information system will be very low. In the process of actual use, the information system is combined with forward and reverse logistics activities, and to avoid information transmission of the "bullwhip effect". In addition, the system development, to the electronic commerce, and to keep the attention to the problem of system maintenance and upgrade. Although, now the logistics enterprises gradually increased the importance of reverse logistics, increased the reverse logistics information construction, but there are still some aspects of reverse logistics in China can be further study: one is the type and characteristics of reverse logistics system of information, and information sharing strategies; The second is information technology and implementation effectiveness and quantitative analysis of the correlation of reverse logistics, from the aspects such as economy and customer service quality to consider; Three is based on the information technology construction of general decision-making model of reverse logistics.

\section{References}

[1] LANGUAGE IN ACCOUNTING Unit One, ACCOUNTING Profession, p. 74-751

[2] Chun-hua deng. The financial accounting risk prevention. China financial economic publishing house.

[3] Chang Xun. Four major financial accounting problems. China financial economic publishing house, in January 2005, the second page. P. $32 \sim 87$

[4] Gary, c.. Improve enterprise financial reporting problems research [M]. Beijing: China financial economic publishing du, 2002 (7),p. $19 \sim 30$

[5] Tian Kun Confucianism. Disclosure: the determinants of corporate governance [J]. Nankai management review, 2001 (1),p. 43-67

[6] Zhanglin. Financial report preparation and analysis [M]. Harbin: heilongjiang people's publishing house, 2004 (6) ,p. 56-2004

[7] Karl min ku core. Limitations and Suggestions for improvement of current financial report [J]. Modern audit and economy, 2008, (2),p. 18-69

[8] Gui-juan zhao, pei-zhen li, MinXiangDong. Discuss the limitations of the current financial report and its improvements [J]. Metallurgical accounting, 2002, (1),p. 18 to 20

[9] Zhang Yunqing. The limitations of the current financial report in our country and the improvement measures [J]. Journal of hebei enterprises, 2007, (9),p. 10-11

[10] King li. The limitations of the current financial reports and Suggestions for improvement [J]. Journal of theory, 2002, (8) :,p. 63-64

[11] Jun-qing li. Try to talk about the limitations of the current financial report and improvement strategies [J]. Journal of information science and technology, 2007, (22) ,p. 533-558 